\title{
The Dairy Queen Cases: A Suggested Approach to the Taxation of Franchise Sales
}

The substantial growth of service franchise systems in the last two decades has raised at least one significant tax problem: whether to tax the gains on transfers of subfranchises by territorial franchisors at ordinary or capital gains rates. In the typical situation the franchise system is organized on three levels. ${ }^{1}$ The national organization holds the relevant trademarks and patents to machinery on which the franchise is based and may manufacture some of the equipment for operators. From the national operator, the territorial franchisor acquires a franchise for one or more states and then divides this territory into subfranchises which he transfers to operators, sometimes reserving part of the territory for his own operation. ${ }^{2}$ The subfranchise "sale" price received by the territorial franchisor is often indeterminate and in part contingent on future sales by the subfranchisee. ${ }^{3}$ The courts have attempted to deal with the problem of whether to tax the gains from these sales as ordinary income or capital gains in a series of cases known as the Dairy Queen cases. ${ }^{4}$

I This characterization refers primarily to the service franchise rather than to the manufacturer-retailer or wholesaler-retailer arrangements which are also franchise systems. The service franchise is built around a service sponsored by the franchisor and is predominant in such fields as soft ice cream drive-ins, food drive-ins, restaurants, motels, auto rentals, and part-time help agencies. This type of franchise is probably the fastest growing form, and it is with this area that this comment will be concerned. Hall, Franchising-New Scope for an Old Technique, Harv. Bus. Rev., Jan.-Feb. 1964, p. 63.

2 KURSh, THE Franchise BoOM 18 (1962).

3 See Kursh, The Franchise Boom, Appendix B (1962). In the Dairy Queen cases the subfranchisee usually pays a lump sum initially in addition to the contingent payments.

4 See Wernentin v. United States, 354 F.2d 757 (8th Cir. 1965); Moberg v. Commissioner, 310 F.2d 782 (9th Cir. 1962); Estate of Gowdey v. Commissioner, 307 F.2d 816 (4th Cir. 1962); Moberg v. Commissioner, 305 F.2d 800 (5th Cir. 1962); and Dairy Queen of Okla., Inc. v. Commissioner, 250 F.2d 503 (10th Cir. 1957).

Although the problem has thus far concerned only Dairy Queen franchises, the classification for taxation of proceeds from the transfer of subfranchises could have a major impact on the burgeoning service franchise systems. The Dairy Queen method of organization is a common one, and the territorial franchisor often derives a major part of his income from his share in subfranchise proceeds. KURSH, The Franchise BOOM 18 (1962); Hall, Franchising-New Scope for an Old Technique, Harv. Bus. Rev. Jan.-Feb. 1964, pp. 60,66. Whether these gains are taxed at capital gains or ordinary rates affects the territorial franchisor's net gain. If the gains are taxed at ordinary rates, the decreased profit may be absorbed at the territorial level or passed on to the operator in increased costs for his operating franchise, but in either case, it makes franchising at one level or the other a less attractive proposition. If the added tax costs cannot be passed on at the 
Two general requirements for capital gains treatment are that the subject of the transaction must be property, and it must be sold or exchanged. ${ }^{5}$ In the Dairy Queen cases the courts have conceded that a franchise is property. ${ }^{6}$ The critical question for the courts has been whether conditions imposed in the contracts between franchisor and subfranchisee ${ }^{\tau}$ transform purported sales into licensing agreements and thus require that gains be taxed at ordinary rates. ${ }^{8}$

The sale and exchange approach has resulted in great diversity of opinion. The Tax Court has steadfastly held that the transfer of subfranchises is not a sale for tax purposes and that all gains are taxable

territorial level, the taxation could result in a shift away from the use of the territorial middleman.

Where the territorial level of franchise organization does not prevail, the problem of taxation of gains from the sale of subdivisions of the master franchise may still arise if the national franchisor tries to claim capital gains on his sale of individual operating franchises or of territorial franchises. Sales of operating franchises directly from the national level in any successful system are likely to be very numerous and to require considerable sales activity. Gains on such sales could be barred from receiving capital gains treatment because they represent gains on capital assets held primarily for sale in the ordinary course of business. See INT. REv. CODE OF 1954, § 1221(1). For discussion of the sale in the course of business problem with regard to subfranchise sales at the territorial level, see text accompanying notes 90-114 infra.

5 INT. Rev. CoDE OF 1954, \$\$ 1221, 1222.

6 See cases cited supra note 4. The Wernentin court took no stand on the question, noting only that the parties had not raised the property issue. United States v. Wernentin, 354 F.2d 757, 762 (8th Cir. 1965).

It has been suggested that this assumption that a franchise is property within the Internal Revenue Code definition bears closer analysis. 52 VA. L. REv. 367 (1966). Past decisions, however, support the courts' classification in the Dairy Queen cases. United States v. Jones, 194 F.2d 783 (10th Cir. 1952) (rights in a bus franchise were a capital asset); Jones v. Corbyn, 186 F.2d 450 (10th Cir. 1950) (exclusive agency held a capital asset). Decisions denying the gains from sales of franchises or exclusive agencies capital gains treatment are often not directly in point because they involve the liquidation of the asset in its return to the grantor and thus run afoul of the courts' requirement that the asset must survive the transfer in order for there to be a sale or exchange. See, e.g., Commissioner v. Starr Bros., 204 F.2d 673 (2d Cir. 1953) (release from exclusive sales agency held not to produce capital gain). See also Commissioner v. Ferrer, 304 F.2d 125 (2d Cir. 1962), which provides a definition of intangible capital assets based on an equitable right to sue.

7 The controversial conditions in the Dairy Queen contracts involved attempts by the territorial franchisor to set standards on such matters as the cleanliness of the operating outlet, the quality of materials, the range of products sold, and the availability of accounts for inspection, and to enforce these provisions through a right of termination on any material contract breach. See Moberg v. Commissioner, 305 F.2d 800, 802-04 (5th Cir. 1962), for a series of contracts indicating the range of conditions generally included in Dairy Queen contracts.

8 United States v. Wernentin, 354 F.2d 757, 762 (8th Cir. 1965); Moberg v. Commissioner, 310 F.2d 782 (9th Cir. 1962); Estate of Gowdey v. Commissioner, 307 F.2d 816, 818 (4th Cir. 1962); Moberg v. Commissioner, 305 F.2d 800, 805 (5th Cir. 1962); Dairy Queen of Okla., Inc. v. Commissioner, 250 F.2d 503, 504 (10th Cir. 1957). 
at ordinary rates, ${ }^{9}$ and this position has been substantially accepted by the Eighth and Ninth Circuit Courts of Appeals. ${ }^{10}$ However, the Fourth, Fifth, and Tenth Circuit Courts of Appeals have found sales and allowed the territorial franchisors capital gains treatment in very similar transactions. ${ }^{11}$ There is also confusion about what consequences should follow a finding of sale. The Fourth and Fifth Circuit Courts of Appeals have distinguished the two common forms of payment, giving capital gains treatment to lump sums paid for the subfranchise but taxing contingent payments arising from the same transactions at ordinary rates, ${ }^{12}$ while the Ninth and Tenth Circuits afford all payments capital gains treatment once the sale and exchange requirement is satisfied. ${ }^{13}$

The purpose of this comment is to evaluate the courts' opinions and to suggest that in dealing with the Dairy Queen type of transaction the sale or exchange requirement is not a helpful tool of analysis with which to determine whether gain from subfranchise transfers is ordinary income or capital gain. Rather, it is more promising to analyze the transfers by the territorial franchisors in terms of property held primarily for sale to customers in the ordinary course of business.

\section{The Dairy Queen CASES}

In the first of the Dairy Queen cases, Dairy Queen of Oklahoma, Inc. v. Commissioner, ${ }^{14}$ the Tenth Circuit Court of Appeals allowed the franchisor capital gains treatment. The franchise agreement between the territorial franchisor and each of his subfranchisees is typical of all the contracts involved in the Dairy Queen cases and included the following provisions: (1) the subfranchisee must obtain mix from a source approved by the franchisor, (2) the franchisor shall have the right to audit the records of the subfranchisee, (3) the subfranchisee shall maintain the standards and quality set up for supplies by the

9 Theodore E. Moberg, 35 T.C. 773 (1961); Dairy Queen of Okla., Inc., 26 T.C. 61 (1956).

10 United States v. Wernentin, 354 F.2d 757 (8th Cir. 1965); Moberg v. Commissioner, 310 F.2d 782 (9th Gir. 1962).

11 Estate of Gowdey v. Commissioner, 307 F.2d 816, 818 (4th Gir. 1962); Moberg v. Commissioner, 305 F.2d 800 (5th Cir. 1962); Dairy Queen of Okla., Inc. v. Commissioner, 250 F.2d 503 (10th Gir. 1957).

12 Moberg v. Commissioner, 365 F.2d 337 (5th Cir. 1966); Estate of Gowdey v. Commissioner, 307 F.2d 816, 820 (4th Cir. 1962) (supplemental opinion).

13 Moberg v. Commissioner, 310 F.2d 782 (9th Cir. 1962); Dairy Queen of Okla., Inc. v. Commissioner, 250 F.2d 503 (10th Cir. 1957). The Moberg court held that the contract conditions prevented sale in most of the contracts before it, but for the one group of contracts in which conditions were minimal, it afforded both lump sum and contingent payments capital gains treatment.

14250 F.2d 503 (10th Cir. 1957). 
territorial franchisor, (4) the same standards shall be maintained with respect to cleanliness and sanitation, (5) no products other than Dairy Queen shall be sold. Furthermore, the contract could not be assigned without permission of the franchisor, and the franchisor could terminate the agreement if the subfranchisee violated any material obligations of the contract. ${ }^{15}$ The subfranchisee agreed to pay a lump sum on delivery of each machine and an additional amount for each gallon of mix processed. The court stated that the grant would not be a sale for tax purposes if the contractual restrictions resulted in the reservation of a "proprietary right," i.e., effective control over the property. ${ }^{16}$ But it reasoned that this control was not retained here because: (1) the power to exclude others, the traditional test of ownership, had been passed to the subfranchisee; (2) the territorial franchisor had no right to interfere with the franchisee's exclusive right to make and sell the products so long as the conditions were complied with and, therefore, the conditions were conditions subsequent; and (3) the conditions were intended to insure uniform product standards for the protection of the parties to the contract ${ }^{17}$ and not to reserve any proprietary right. ${ }^{18}$

In Estate of Gowdey v. Commissioner, ${ }^{19}$ Gowdey had entered into fourteen franchise agreements with conditions substantially the same as those in Dairy Queen of Oklahoma. ${ }^{20}$ Allowing the proceeds capital gains treatment, ${ }^{21}$ the Fourth Circuit Court of Appeals pointed out that the property rights were transferred in perpetuity, an indicium of an absolute estate. ${ }^{22}$ In addition, the court reiterated the general rule stated in Dairy Queen of Oklahoma that there must be a transfer of all substantial rights in the property, but then noted that reasonable restrictions may be placed upon those rights. ${ }^{23}$ Underlying this reason-

15 See Dairy Queen of Okla., Inc., 26 T.C. 61, 66-67 (1956), for the complete contract. 16 Dairy Queen of Okla., Inc. v. Commissioner, 250 F.2d 503, 506 (10th Cir. 1957).

17 Id. at 506.

18 The dissenting judge looked at the effect of the conditions imposed on the subfranchisee. He concluded that the subject matter of a franchise could not be separated from the franchise, and that here the subject matter, Dairy Queen ice cream, was effectively controlled from manufacture to sale. $I d$. at 507 .

19307 F.2d 816 (4th Cir. 1962).

20 Id. at 819.

21 The court cited Dairy Queen of Okla., Inc. v. Commissioner, 250 F.2d 503 (10th Gir. 1957), and noted that it was persuaded further "by the broad view of the practical aspects of the problem in that decision." Estate of Gowdey v. Commissioner, 307 F.2d 816, 820 (4th Cir. 1962). (The broad view, presumably, was recognition of the need for uniformity, 250 F.2d at 506).

22307 F.2d at 820 .

23 Id. at 818-19. For examples of restrictions which have been considered reasonable, see text accompanying notes 53-61 infra. 
ing was the further assumption that the restrictions were necessary to secure the contingent payments. ${ }^{24}$

In Moberg $v$. Commissioner, ${ }^{25}$ the territorial franchisor transferred thirty-seven subfranchises using several form contracts. These contracts varied from that used in Dairy Queen of Oklahoma principally in the greater flexibility of the franchisor's right to approve ${ }^{26}$ quality of supplies, cleanliness, accounting methods, and the sale of additional products. The Fifth Circuit Court of Appeals found that all contracts accomplished sales for tax purposes on the theory that the exclusive right to use the machines, the mix formula, and the trade name passed to the purchaser. Furthermore, the restrictions were designed "to maintain quality, sanitary dispensing conditions, uniform standards for the trade named product, protect each subfranchise purchaser as against other purchasers in respect to territory, protect the seller in respect to the contract with the [national organization], and to insure the ascertainment and collection of contractual sums due," none of which was inconsistent with the requirement of sale or exchange. ${ }^{27}$

These same Moberg contracts came before the Ninth Circuit Court of Appeals in 1962 in Moberg $v$. Commissioner. ${ }^{28}$ The territorial franchise involved was owned by two brothers and the original tax court de-

24 Id. at 819 .

25305 F.2d 800 (5th Cir. 1962).

26 Id. at 803,804 . The contracts provided that:

(3) The bookkeeping system employed by the buyer is subject to approval by petitioners ...

-..

(7) 'All mixes and supplies' ... must meet 'standards of quality and specifications approved' by petitioners,

(8) The buyer is to paint and maintain the . . premises by 'standards of quality and cleanliness now or hereafter set up by' the petitioners,

(9) The buyer may sell no product other than Dairy Queen without approval of petitioners.

Theodore E. Moberg, 35 T.C. 773,779 (1961).

The provisions for approval of supplies and maintenance do not differ materially from those in Dairy Queen of Okla., Inc., 26 T.C. 61, 66-67 (1956), except for the phrase "now or hereafter set up" in clause (8), which makes clear the company's later ability to change the standard. Also, the approval of the franchisor was not part of conditions (3) and (9) in the earlier contracts where, for example, (9) read: "No other products . . . shall be sold ...." The Fifth Gircuit did not consider the differences to be material enough to distinguish Dairy Queen of Oklahoma, but the Ninth Circuit Court of Appeals, dealing with the same contracts in Moberg v. Commissioner, 310 F.2d 782 (9th Cir. 1962), found that the approval provisions gave the franchisor the right to continually change the standards which the franchisee must meet and held that the sale and exchange requirement was not satisfied.

27 Moberg v. Commissioner, 305 F.2d 800, 806 (5th Cir. 1962).

28310 F.2d 782 (9th Cir. 1962). 
cision $^{29}$ had dealt with both, but different residences of the two Mobergs resulted in appeal of that decision to both the Fifth and Ninth Circuits. Unlike the Fifth Circuit, the Ninth Circuit Court of Appeals found that most of the contracts did not accomplish sales for tax purposes. The court's test was whether the reservations and restrictions rendered the grant a transfer of something less than "all substantial rights" of the grantor to the subject matter of the grant.$^{30}$ For all contracts where the conditions were drafted so that the subfranchisees' actions were subject to the approval of the franchisor, the court held that the approval phrasing represented a power to change and adjust conditions on a continuing basis and were equivalent to active operational control. ${ }^{31}$ The court did not consider the case where conditions are fixed, although the one form contract which the court found accomplished sale differed from the others primarily in this respect. ${ }^{32}$

In United States $v$. Wernentin, ${ }^{33}$ decided in 1965 and the latest case in the series, the territorial franchisor sold his entire territorial franchise to a single purchaser, several counties at a time. The contracts were similar to those in Dairy Queen of Oklahoma, except that the franchisor had the additional right to terminate for failure to develop the territory. ${ }^{34}$ However, after the transfer of the franchise, the franchisor provided continuing assistance to the franchisee in the form of blueprints and formulae, a regular bulletin to operators, leadership at the New Jersey meetings, and part payment of the cost of such meetings. ${ }^{35}$ The court distinguished the earlier Dairy Queen cases by this continuing pattern of assistance and denied capital gains treatment because of the transferor's active commercial participation..$^{36}$ Although Wernentin is distinguishable from the preceding cases because of the continuing assistance, it nonetheless clearly describes the central conflict in the franchise cases:

29 Theodore E. Moberg, 35 T.C. 773 (1961).

30 Moberg v. Commissioner, 310 F.2d 782 (9th Cir. 1962).

31 Id. at 784 .

32 Id. at 783, and note 1 supra.

33354 F.2d 757 (8th Cir. 1965).

$34 \mathrm{Id}$. at 760 .

35 Id. at 761 .

36 Id. at 766. Considered singly, the conditions are similar to those in all of the other cases and should be dealt with similarly. Although the post-contract assistance by the franchisor is relevant to the intent of the parties to sell or to license, it is not of itself determinative of the issue. There are other motives which could explain this assistance besides intent to retain control. It could simply reflect the desire to assist a less experienced businessman and to help make his operation profitable in order to insure regular payment of the purchase price. Where the later conduct and participation are not provided for by the contract and are not forced on the subfranchisee, they do not necessarily represent control rather than temporary assistance. 
[T] he courts appear to be struggling to accommodate, on the one hand, the continuing interest of the transferors whose compensation is largely dependent on future profitable use of the transferred rights with, on the other hand, the traditional notion that a seller divests himself of substantially all control over property sold. ${ }^{37}$

\section{The Policy Basis For Gapital Gains}

In order to evaluate the courts' varying approaches to franchise sales in the Dairy Queen cases, it is necessary to examine the policies underlying capital gains taxation. Reading backward from the commentary, one could postulate a model capital gains transaction containing the following elements: ( 1 ) gains resulting from appreciation of the market value of a capital asset, (2) appreciation which has built up slowly over a long holding period, (3) gains which tend to be non-recurring, and (4) gain realized in a return of the asset to the same market from which it was purchased for a lump sum consideration..$^{38}$ Several unjust results were thought to follow from taxation of this model at ordinary rates. First, since the gains are generally non-recurring and represent value appreciation over a long period, the taxation of the gain as ordinary income in the year of realization would result in the bunching of income, leading, under the progressive rate structure, to taxation at a higher rate than if such gain had been taxed as it accrued..$^{39}$ Second, when the gain is taxed at ordinary rates in the year of realization, this may have an undesirable effect on liquidity of investment, giving rise to what has been called the "lock-in" problem: ${ }^{40}$ an investor faced with a high rate of taxation on disposition may be deterred from selling and

\section{Ibid.}

38 This model is a composite of various ideal characteristics usually discussed singly. See ali Discussion Draft of a Study of Definitional Problems in Capital Gains Taxation 226 (1960); Seltzer, The Nature and Tax Treatment of Capital Gains and Losses 3 (1951); Note, Distinguishing Ordinary Income from Capital Gains Where Rights to Future Income Are Sold, 69 HARv. L. REv. 737, $739-40$ (1956).

39 Commissioner v. Gillette Motor Transport, 364 U.S. 130, 134 (1960); H.R. REP. No. 1388, 67th Cong., 4th Sess. 1-2 (1923); H.R. REp. No. 350, 67th Cong., Ist Sess. 10-11 (1921); ali Discussion Draft of a Study of Definitional Problems in Capital Gains Taxation 187-89 (1960); U.S. Treasury Def'x. TaX Advisory Staff, Federal Income TaX Treatment of Capital Gains and Losses 13, 21 n.35 (1951).

40 Commissioner v. P. G. Lake, 356 U.S. 260, 265 (1957); Burnet v. Harmel, 287 U.S. 103, 106 (1932); H.R. REP. No. 2333, 77th Cong., 2d Sess. 29 (1942); S. REP. No. 1631, 77th Cong., 2d Sess. $49-50$ (1942); ALI Discussion Draft of a Study of Definitional Problems in Capital Gains Taxation 183-86 (1960); U.S. Treasury Tax Advisory Staff, Federal Income Tax Treatment of Capital Gains and Losses 13 (1951); Brown, The Locked-In Problem, printed in Cong. JT. Comm. ON THE ECONOMxg REPORT, 84Th CONG., IST SEsS., Federal Tax Policy for Economic Growth and Stability 367 (1955). 
shifting his capital to more lucrative investments, thereby adversely affecting the national mobilty of investment and economic growth. The tax concessions have also been justified as a stimulus to investment. $^{41}$

However, few transactions raise all of the problems that the capital gains law was designed to meet. To aid in effectuating capital gains policy, Congress established standards to separate capital gains from ordinary income. The two of these that are especially relevant to the franchise problem are that capital gain treatment results only from a sale or exchange and that gain arising from sale of property held primarily for sale in the ordinary course of business is ordinary income. These standards are helpful introductory tools for analysis, but they provide ultimate answers only in obvious cases. Where the question is close, as in the franchise cases, it becomes important to look beyond these requirements to see whether the transactions involved raise the problems that the capital gains law was designed to meet. ${ }^{42}$

\section{Sale And Exchange-The Requirement of Complete Disposition}

The requirement of complete disposition ${ }^{43}$ was designed in part to prevent the conversion of ordinary income into capital gains, either through complex holding patterns or leasing arrangements. ${ }^{44}$ For example, the investor in a franchise or other asset could transfer title to another, retaining control through provisions in the sale contract, in return for payment based on the income from the asset. Absent a requirement of complete disposition, he could retain virtually complete control of the asset while converting its income into capital gains.

In applying the complete disposition requirement to the Dairy Queen cases, the courts have focused on the question whether the con-

41 McCracken, Taxation and Capital Formation, U.S. Cong. Jr. CoNm. on THE Economic Report, 84th Cong., Ist Sess., Federal TaX Policy for Economig Growth and Stability 142 (1955).

42 See Casenote on United States v. Wernentin, 80 HARv. L. REv. 455 (1966), for a brief attempt at applying these policies to the Dairy Queen transactions within the sale and exchange frame of analysis.

43 INT. REv. CODE of 1954, § 1222, requires the "sale or exchange" of a capital asset for capital gains treatment. For the purposes of franchise sales complete disposition is used here to refer to the sale or exchange requirement in order to avoid the complications of that requirement which are not relevant here, such as the need for consideration or the rule that the asset must survive the transfer. See Note, The Elements of a Section 117 "Sale or Exchange," 53 CoLUM. L. REv. 976 (1953). In the franchise cases there is consideration, and the subfranchisor holds the asset after transfer; accordingly, the only problem under the sale requirement is whether the transferor has relinquished control.

44 Surrey, Definitional Problems in Capital Gains Taxation, 69 HARv. L. REv. 985, 1000 (1956). 
ditions in the contracts of sale constitute a sufficient reservation of control to render the disposition incomplete. The Senate Finance Committee which reported the special capital gains patent provision attempted to distinguish permissible conditions from incomplete disposition in the following manner:

Rights . . . which are not inconsistent with the passage of ownership such as a security interest (i.e., a vendor's lien) or a reservation in the nature of a condition subsequent (e.g., a forfeiture on account of non-performance) are not to be considered as such a retention as will defeat the applicability of this section. On the other hand, a transfer terminable at will by the transferor would not qualify. ${ }^{45}$

But the Committee left open the classification of transactions falling between these two poles.

Conditions which reserve a security interest have not prevented a sale for capital gains purposes and have been allowed considerable breadth in sales of trademarks, copyrights, and patents. The reason for this liberal treatment of security conditions is that payment for the sale of those assets is typically extended over time and the seller needs some retained interest in the property to insure that he is paid. ${ }^{46}$ Therefore, the courts have held that the reservation of a right to terminate for the transferee's default in payment ${ }^{47}$ or for his dissolution, bankruptcy, or receivership ${ }^{48}$ does not prevent a sale for tax purposes. In patent, copyright, and trademark sales, however, these simple non-payment provisions are insufficient protection for the seller because the form of payment is not only extended but is also contingent on future sales. Unlike other forms of property, such as land or corporate shares, for which there is usually a clear market price, patents, copyrights, and trademarks involve a high degree of risk in their exploitation which makes it very difficult to value them before exploitation. A lump sum

45 F. H. Philbrick, 27 T.C. 346, 355-56 (1956), quoting SEN. REP. No. 1622, 83d Cong., 2d Sess. $439-40$ (1953). The Senate Finance Committee Report defines the "all substantial rights" standard of $\S 1235$ of Internal Revenue Code of 1954, but the Committee saw this standard as a restatement of the sale or exchange requirement, incorporating its basic criteria.

46 Commissioner v. Celanese Corp. of America, 140 F.2d 339, 342 (D.C. Cir. 1944); F. H. Philbrick, 27 T.C. 346, 355-56 (1965). See Bailey, The Inventor, N.Y.U. I5TH INST. ON FED. TAX 285, 301 (1957); Fraser, Foreign Licensing-U.S. Tax Aspects, 6 B.C. IND. \& CoMm. Rev. 509, 513-14 (1965).

47 Merck \& Co. v. Smith, 261 F.2d 162 (3d Cir. 1958); First Nat'l Bank of Princeton v. United States, 136 F. Supp. 818 (D.N.J. 1955); Lamar v. Granger, 99 F. Supp. 17 (W.D. Pa. 1951).

48 Merck \& Co. v. Smith, 261 F.2d 162 (3d Cir. 1958); Commissioner v. Celanese Corp. of America, 140 F.2d 339 (D.C. Cir. 1944); Carl G. Dreymann, 11 T.C. 153 (1948). 
sale price would have to be small in order to attract buyers, but a low sale price would deprive the seller of his share in the profits from a successful book or invention. In order to fairly allocate risk and profits, it is customary to base the price on future sales or quantities produced. ${ }^{49}$ However, this extended form of payment contingent on sales leaves the seller at the mercy of the buyer not only if the latter does not pay but also if he does not exploit the property. Therefore, so long as payments continue-often for the life of the asset-provisions to secure effective exploitation, as well as simple payment of sums due, have been held consistent with the sale and exchange requirement. ${ }^{50}$

The necessity of a contingent form of payment justifies retention of a broad security interest in patent, copyright, and trademark sales. But such contingent payments should not be used to justify a continuing interest in the sale of other capital assets for which a reasonable lump sum price is not difficult to determine. If the asset creates no need for payment contingent on sales, then broad conditions are not required for security and should be viewed as continuing control by the seller resulting in a licensing transaction rather than a sale.

Franchises, like copyrights, patents, and trademarks, involve similar risks of exploitation which make it difficult to set a fair price..$^{51} \mathrm{~A}$ beginning franchise system has no established trade name, an often untested product, and little of the management assistance characteristic of an established national organization. Accordingly, a fixed price which would attract operators would have to be unremunerative to the seller and would deprive him of his share of the gains should the operation prove profitable. Conversely, a fixed price which would assure the seller a fair share of optimistically predicted gains would be prohibitive to purchasers who would then be forced to bear most of the risks of failure. Even after the system is established, it is difficult to estimate the worth of any new market or operating location. The nature of the asset

49 Ali Discussion Draft of a Study of Definitional Problemis in Gapital gains TAXation 247 (1960).

50 See text accompanying notes 53-60 infra.

51 KURSh, The Franchise Boom 60 (1962). Some territorial franchisors have had to give away franchises in order to interest early operators.

It should be noted that there is a second business reason for the use of contingent payments in the franchise context. The purpose of the franchise form of organization is to involve local individuals-essentially independent merchandisers-in an operation with national contacts and reputation; and in order to insure truly local ownership, the franchise companies have kept the initial investments required of operators relatively low, with most of the compensation deferred through contingent payments. Id. at 34 (1962). Thus, the form of payment responds not only to risk but also to the need of the system to decentralize, and this latter factor buttresses the need for the contingent form of payment. 
and the risks of exploitation make payments contingent on sales reasonable, and these payments require the same security that the courts have held consistent with capital gains treatment for gains on other intangible rights.

In the sales of patents, copyrights, and trademarks, the courts have held that provisions requiring that the grantor have access to the transferee's books, ${ }^{52}$ that the grantee practice the invention ${ }^{53}$ or use his best efforts in marketing ${ }^{54}$ or keep patents in full force and effect, ${ }^{55}$ and that he expand his outlets within a given period, ${ }^{56}$ do not violate the requirement of sale for capital gains treatment. Requirements for quality maintenance have also been held consistent with sale. ${ }^{57}$ Limita tions on assignments have not barred capital gains treatment, ${ }^{58}$ nor have reservations of rights to terminate for breach of any conditions or obligations in the contract. ${ }^{59}$ Provisions for termination at will, on the other hand, are not reasonable security conditions. ${ }^{60}$

Some provisions in the Dairy Queen contracts, such as those requiring that records be kept, that payments be made, and that assignment of the subfranchise be made only with the franchisor's approval, ${ }^{61}$ are very similar to conditions held consistent with the sale requirement in cases involving other intangible rights. ${ }^{62}$ Dairy Queen agreements also provide for standards of cleanliness, quality of materials, and the range of products to be sold. ${ }^{63}$ These appear to be analogous to the courtsanctioned requirements for using best efforts in marketing ${ }^{64}$ or for maintaining quality standards. ${ }^{65}$ The specificity of the Dairy Queen

52 Kimble Glass Co., 9 T.C. 183 (1947).

53 Merck \& Co. v. Smith, 261 F.2d 162 (3d Cir. 1958).

54 Kronner v. United States, 110 F. Supp. 730 (Ct. Gl. 1953); F. H. Philbrick, 27 T.G. 346,350 (1956).

55 Commissioner v. Celanese Corp. of America, 140 F.2d 339 (D.C. Cir. 1944).

56 Kronner v. United States, 110 F. Supp. 730 (Ct. Cl. 1953).

57 Seattle Brewing \& Malting Co., 6 T.C. 856 (1946), aff'd, 175 F.2d 216 (9th Cir. 1948).

58 Rollman v. Commissioner, 244 F.2d 634 (4th Cir. 1957); Lawrence v. United States, 242 F.2d 542, 545 (5th Cir. 1957); Allen v. Werner, 190 F.2d 840 (5th Cir. 1951).

59 Lawrence v. United States, 242 F.2d 542, 545 (5th Cir. 1957); Allen v. Werner, 190 F.2d 840 (5th Cir. 1951). See also Treas. Reg. $\$ 1.1235-2(\mathrm{~b})(2)(\mathrm{ii})$ (provisions for total forfeiture for non-performance are not per se inconsistent with the passage of ownership).

60 Young v. Commissioner, 269 F.2d 89, 94 (2d Cir. 1959); Magnus v. Commissioner, 259 F.2d 893, 899 (3d Cir. 1958); Lynne Gregg, 18 T.C. 291, 302 (1952), aff'd, 203 F.2d 954 (3d Cir. 1953).

61 These conditions are common to all the Dairy Queen contracts. See text accompanying note 15 supra.

62 See Kimble Glass Co., 9 T.G. 183 (1947) (records); Merck \& Co. v. Smith, 261 F.2d 162 (3d Cir. 1958) and First Nat'l Bank of Princeton v. United States, 136 F. Supp. 818 (D.N.J. 1955) (payments); Allen v. Werner, 190 F.2d 840 (5th Cir. 1951) (assignment).

63 See text accompanying note 15 supra.

64 See note 54 supra.

65 See note 57 supra. 
conditions would seem to make them more justifiable under the sale or exchange requirement than general provisions for the use of best efforts or quality control, because specificity limits the intervention of the transferor to certain conduct and may decrease his ability to exert broad operational control.

In the Moberg case the Ninth Circuit Court of Appeals emphasized the difference between fixed conditions and those providing for continuing approval, and held that the approval conditions made the transfer a mere license. The Moberg court noted that fixed standards "were enforceable only by the grantor's power to terminate the entire transaction and did not subject grantees to the possibility of piecemeal future intervention by and at the will of the grantors." assume that fixed conditions are unchangeable; but such conditions are unchangeable only if they are drafted with great exactness, and this is not true of the Dairy Queen conditions or of those traditionally allowed for security. Implicit in a condition which simply states that a high standard of quality in mix or product shall be met is the option of the franchisor to decide what a "high standard" is and when it is met. The addition of a clause specifically providing for the franchisor's approval only makes this step explicit, and under either form of condition, the only remedy for breach is termination. The two forms of the same conditions present in the Dairy Queen cases should be treated identically, since both are similar to security provisions which the courts have held consistent with the sale requirement for capital gains treatment.

Proliferation of these security conditions is limited by the requirement that substantially all rights of ownership must be released to the transferee if the transferor's gain is to be taxed as capital gain. ${ }^{67}$ If the security interest is so extensive that it hardly differs from the investment interest which is purported to be sold, then the transaction is not a sale for tax purposes. In the Dairy Queen cases the franchisor retains only the right to insure, through a right of termination, that certain levels of cleanliness and product quality be maintained and that only Dairy Queen products be sold. These rights do not approach the level of control the franchisor had in the property before the transfer, and they are reasonably related to protection of his payments. The franchisee has a perpetual right to the use of the trade name, the secret process, and the patented machines, the right to sell the product in an exclusive area, and operational control over marketing, employees, hours, flavors, and financing. The franchisee's inability to sell low quality products at un-

66 Moberg v. Commissioner, 310 F.2d 782, 783 n.I (9th Cir. 1962).

67 Schmitt v. Commissioner, 271 F.2d 301 (9th Cir. 1959). 
sanitary premises hardly constitutes a major restriction on his activity and control.

The contract conditions in the Dairy Queen cases are designed to guarantee uniformity as well as security of payment, and such conditions do not conflict with the requirement of complete disposition. ${ }^{68}$ The contract provisions preserve the value of the franchisor's remaining property and further a general purpose of the franchise system. Franchising usually involves a large group of small businessmen under the umbrella of a national image ${ }^{69}$ created by maintaining uniform, high quality operations. The need for uniformity, unlike that for security, does not depend on any continuing stream of payments and is equally relevant where a lump sum is paid. The situation is similar to transfers of land upon condition that it be used only for residential housing to protect the value of surrounding property still held by the seller. Presumably, such a reservation would have no effect on a finding of sale for tax purposes. The conditions are designed for the prevention of possible injury to the business of the seller from misuse by the buyer of the thing sold, and as such they serve a legitimate business need and are not mere disguises for the retention of control. Under the sale requirement it does not seem appropriate to deny capital gains treatment to gains from subfranchise transfers on the basis of these contract conditions so long as they are reasonably necessary for security and uniformity.

\section{Contingent Payments}

Even after a sale has been found, the Dairy Queen courts have encountered the problem of how to handle the extended payments made to the franchisor. ${ }^{70}$ The Dairy Queen subfranchisees pay the franchisor both a lump sum at the time the franchise is transferred and a set amount per each gallon of mix sold thereafter. In almost all of the con-

68 See Moberg v. Commissioner, 305 F.2d 800, 806 (5th Cir. 1962); Estate of Gowdey v. Commissioner, 307 F.2d 816, 819 (4th Cir. 1962); Dairy Queen of Okla., Inc. v. Commissioner, 250 F.2d 503, 506 (10th Cir. 1957).

69 See generally Kursh, The Franchise Boom (1962); Hall, Franchising-New Scope for an Old Technique, Harv. Bus. Rev., Jan.-Feb. 1964, p. 60, 72. The Small Business Administration recognized the value of this image in its description of the franchise system: "The business starts out with an established product or service reputation. It is organized and operated with the advantages of 'name' and standardization." Quoted in Kursh, THE FRANCHYSE BOOM 15 (1962) from an unpublished report.

70 The reason for the adoption of this form of payment and its relevance in supporting retention of a security interest have been discussed above. However, once a sale has been found, the question remains whether these contingent payments should be given capital gains treatment. 
tracts the gallonage payments represent the major part of the total compensation, even over the short period considered by the courts. ${ }^{71}$

Unlike the lump sum payments, continuing payments provide their own rough averaging system for the gain, thus making any preferential capital gain treatment unnecessary to prevent bunching. In addition, taxation of payments contingent on sales at ordinary rates would not result in lock-in of investment since the transferor would face much the same tax after the transfer as he would if he chose to operate the franchise himself. Accordingly, the tax prospects would not deter him from disposing of the asset.

The inappropriateness of affording capital gains treatment to contingent payments was recognized in United States $v$. Cory, ${ }^{72}$ where the taxpayer had transferred part of a copyright, the book publication rights, in return for a percentage of sales. The court held that the gains were ordinary income, basing its opinion on both the contingent form of payment and the functional division of the copyright. ${ }^{73}$ In the Dairy

71 The lump sum is usually several thousand dollars, and the contingent payments vary from fourteen to thirty-five cents per gallon of mix sold. Occasionally, the lump sum is payable in installments also based on gallonage, but the total amount is fixed.

$\begin{array}{lllc}\begin{array}{l}\text { Dairy Queen } \\ \text { of Oklahoma }\end{array} & & \text { lump sums } & \text { contingent payments } \\ \text { Gowdey } & 1948 & \$ 57,056.45 & \$ 30,434.73 \\ & 1949 & 62,916.89 & 74,575.70 \\ \text { Mobergs } & 1949 & 12,000 & 5,588.10 \\ & 1950 & 44,000 & 30,693.90 \\ & 1948 & 61,842.09 & \\ & 1949 & 67,035.06 & 11,267.18 \\ & 1950 & 53,654.15 & 77,056.86 \\ & & & 131,082.30\end{array}$

The figures represent the total lump sums or contingent payments received by the territorial franchisor during the year. For Dairy Queen of Oklahoma and the Mobergs, the contingent payments were already exceeding lump sums paid in the second year of subfranchise sales, and, of course, the contingent payments continue indefinitely. The sources for the payments are Estate of Gowdey v. Commissioner, 307 F.2d 816, 818 (4th Cir. 1962); Theodore E. Moberg, 35 T.C. 773, 777-78, 780, 782-83 (1961); and Dairy Queen of Okla., Inc., 26 T.C. 61,67 (1956).

72230 F.2d 941 (2d Cir.), cert. denied, 352 U.S. 828 (1956).

73 Cory decided that the contingent payment and the divisions of the asset (i.e., sale of book rights only) together prevented the sale necessary for capital gains treatment. Functional division of copyrights had earlier barred capital gains treatment for copyright gains, but decisions preceding Cory had reversed this rule. See Goldsmith v. Commissioner, 143 F.2d 466, 467 (2d Cir.), cert. denied, 323 U.S. 774 (1944). Rev. Rul. 409, 1954-2 Cum. BuLL. 174. Rev. Rul. 226, 1960-1 Cum. Bull. 26, went farther and amended Rev. Rul. 409, stating that "the consideration received by a proprietor of a copyright for a grant transferring the exclusive right to exploit the copyrighted work in a medium of publication throughout the life of the copyright shall be treated as proceeds from a sale of property, regardless of whether the consideration received is measured by a percentage of the receipts from the sale ... of the copyrighted work ...." In the light of this position of the Commissioner, the present validity of the Cory holding seems questionable. 
Queen transactions the contingent payments are also based on the future sales and the franchise is territorially divided. Under the Cory approach, then, none of the payments would be capital gain. ${ }^{74}$ Alternatively, applying the bunching and lock-in rationale for the capital gains concession, the lump sum might be considered capital gain, but the contingent payments would be ordinary income because they raise none of the problems the tax concession was meant to alleviate.

However, the courts have not accepted the bunching and lock-in analysis, and Cory represents the minority view. Section 1235 of the Code, ${ }^{75}$ which is limited to patent sales, accepts the position of the courts before $1954^{76}$ that the form of payment is irrelevant in classifying the gain on sale as capital gain. The courts have extended this protection of contingent payments to copyrights ${ }^{77}$ and trademarks, ${ }^{78}$ and in 1960 the Commissioner explicitly recognized the similarity of patent and copyright property. ${ }^{79}$ Reversing a previous stand, ${ }^{80}$ the new revenue ruling states that the form of payment alone does not bar treatment of the transfer as a sale. Furthermore, Jones $v$. Corbyn $n^{81}$ explicity permitted taxation of contingent payments at capital gain rates in the sale of a franchise.

The decision of several of the Dairy Queen courts to tax lump sum gains at capital gains rates and contingent payments as ordinary income fits neither within the Cory rationale nor under the accepted case law. The Gowdey court advanced the theory that the payments based on gallonage were somehow connected with the mix and were not payment for the franchise although there was no evidence that such mix was to be purchased from the franchisor. ${ }^{82}$ The Fifth Circuit Court of Appeals noted in Moberg that contingent payments did not raise the problems that capital gains treatment was designed to meet, and held that these

74 Arguably, Cory can be distinguished from the Dairy Queen cases because that case dealt with functional division and a payment completely contingent on sales, while the franchise cases present a problem of territorial division and of payment in both lump sum and contingent form.

75 INT. Rev. CoDE OF 1954, \& 1235.

76 Commissioner v. Celanese Corp. of America, 140 F.2d 339 (D.C. Cir. 1944); Commissioner v. Hopkinson, 126 F.2d 406, 410 (2d Cir. 1942); Edward C. Myers, 6 T.C. 258 (1936).

77 Commissioner v. Ferrer, 304 F.2d 125 (2d Cir. 1962); Richard W. Telinde, 18 T.C. 91 (1952).

78 Rose Marie Reid, 26 T.C. 622, 632 (1956); Seattle Brewing \& Malting Co., 6 T.C. 856 (1946).

79 Rev. Rul. 226, 1960-1 Cun. BuLL. 26.

80 Rev. RuI. 409, 1954-2 GuM. Bull. 174.

81186 F.2d 450 (10th Cir. 1950).

82 Estate of Gowdey v. Commissioner, 307 F.2d 816, 820 (4th Cir. 1962) (supplemental opinion). 
payments were not part of the purchase price, but instead were a return on an interest retained by the transferor. ${ }^{83}$ This concept of property in the franchise still held by the franchisor is not only inconsistent with the case law which ignores the form of payment once sale has been found, but it is also inconsistent with the rest of the same court's decision. If there is some interest retained in the property for which the contingent payments are a return, then there is no complete disposition as the court had found, and all payments are ordinary income. Under the existing law, which does not accept the denial of capital gains treatment for contingent payments, the Moberg and Gowdey decisions are incorrect in separating the forms of payment. ${ }^{84}$

The Fifth Circuit Court of Appeals in the Moberg decision is clearly responding to the logic that bunching and lock-in problems simply do not exist for contingent payments. ${ }^{85}$ However, the theoretical rationale for capital gains is not explicit, or even implicit, in the statutes, and the exclusion of contingent payments would probably require statutory change. ${ }^{86}$ Judge Friendly stated the judicial attitude toward contingent payments in Ferrer v. Commissioner:

[W] find nothing in the statute [INT. REV. CoDE OF $1954 \S \S$ 1221, 1222] that forbids capital gain treatment because the payment to Ferrer might be spread over a number of years rather than coming in a lump sum; although prevention of the unfairness arising from applying ordinary income rates to a "bunching" of income may be one of the motivations of the "capital gain" provisions, the statute says nothing about this. ${ }^{87}$

The taxation of contingent payments at capital gains rates does not further the purposes of the capital gains concession and should be changed to deny capital gains treatment to such payments. At this point, however, any change will probably have to be made through revision of the Code. Without such statutory revision there is no basis in the franchise context to separate contingent payments for taxation at ordinary rates.

83 Moberg v. Commissioner, 365 F.2d 337, 340 (5th Cir. 1966).

8* The contingent payments could be severed and taxed at ordinary rates if they were compensation for some service performed by the franchisor such as national advertising, but the courts have not identified any such service in distinguishing these payments.

85 Moberg v. Commissioner, 365 F.2d 337, 340 (5th Cir. 1966).

86 For a proposed revision, see AlI Discussion Draft of a Study of Definitional ProbLEMS OF CAPITAL GaINS TAXation 29-32 (1960).

87304 F.2d 125, 133 (2d Cir. 1962). 


\section{Property Held For Sale To Gustomers}

Thus far the franchise tax problem has been discussed in the context in which the courts have placed it, under the sale and exchange provision. But there is a second independent basis for dealing with the problem. The Internal Revenue Code provides that assets held primarily for sale in the ordinary course of business do not produce capital gains on their disposition. ${ }^{88}$ Although the question whether territorial franchisors are in the business of selling subfranchises has been raised, it has not yet been fully explored. ${ }^{89}$

In excluding property held for sale, the Code recognizes that merchandising does not raise the problems that capital gains taxation was designed to meet. ${ }^{90}$ Where there is a regular course of selling, the bunching problem is minimized because the gain resulting from sales activity is taxed in the year it is earned. In addition, the property is generally not held for sufficient periods for the market value appreciation to accumulate. Even if value appreciation does account for part of the gain, a regular pattern of sales averages the gains over time and thus alleviates the bunching problem. There is also little lock-in effect to prevent application of ordinary rates to gains, for where the source of income is selling activity, the tax on sale profits at ordinary income rates is unlikely to induce continued holding of the inventory of a going business.

The Dairy Queen cases, howiever, do not involve simple merchandising, but rather the purchase and active resale of what would ordinarily be investment property. The courts' difficulty in deciding whether the franchisor, or any seller of property, is an investor or merchandiser stems largely from the fact that the gain on the sale of an asset may be the result of both sales activity and market value appreciation. Despite the mixed nature of the gain, the entire profit must be treated as either ordinary income or capital gain. ${ }^{91}$

88 INT. Rev. CODE of 1954, § 1221: "[T] $]$ he term 'capital asset' . . . does not include(1) stock in trade of a taxpayer or other property of a kind which would properly be included in the inventory of the taxpayer if on hand at the close of the taxable year, or property held by the taxpayer primarily for sale to customers in the ordinary course of his trade or business ....."

89 The Tax Court has considered the issue twice on remand. See Vern G. Moberg, 22 CCH Tax Ct. Mem. 1483 (1963); Dairy Queen of Okla., Inc., 18 CCH Tax Ct. Mem. 322 (1959). If analysis in terms of sale in the course of business is accepted, it has several advantages over that of sale and exchange. It avoids the ambiguity of the contractural conditions and requires no analogies to patent and copyright law-and the form of payment has no effect on the outcome. If there is a business of selling, all sales produce ordinary income.

90 See text accompanying notes 40-42 supra.

91 See SurRey \& WARREN, Federal InCOME TAXATION 695 (1962). 
On two occasions courts of appeals have remanded Dairy Queen cases for a determination of whether the territorial franchisors had gone into the business of selling franchises, ${ }^{92}$ and in both cases the Tax Court found that the territorial franchisor was not holding subfranchises for sale in the ordinary course of business. ${ }^{93}$ Dairy Queen of Oklahoma, Inc., had made nineteen sales of subfranchises in 1948 and seventeen sales in 1949.94 Although the taxpayers asserted that their original plan when the assets were acquired in 1946 was to build, own, and operate the stores themselves, the franchisors made their first sale of a subfranchise in 1946 as the result of solicitation by the buyer, and thereafter received continued requests from prospective purchasers. ${ }^{95}$ The agreement to incorporate the partnership recited that the plan to promote the business relied in part on selling franchises for certain specified territories.96 Nonetheless, the Tax Court found that the thirty-six sales were not indicative of a holding for sale to customers in the ordinary course of business because the sales were at no time promoted or solicited by the franchisors. A lack of sales activity and a professed intent to develop the territory himself led to a similar holding in the Moberg case on remand from the Fifth Circuit Court of Appeals. ${ }^{97}$ Moberg had acquired the franchise in 1947 and had made twenty-seven sales from 1947 through $1950 . .^{98}$

Since, as noted earlier, the source of the gain in sales of subdivided property is mixed, the "source" test is not determinative, and in classifying the gain courts have looked instead to the purpose ${ }^{99}$ and selling activities $^{100}$ of the holder of the property. Factors which bear on intent, sales activity, and the source of the gain are: (1) the number of sales, (2) the length of the holding period, (3) the subdivision of the property, and (4) the relation between returns from sales and returns from exploitation of the property.

92 Moberg v. Commissioner, 305 F.2d 800 (5th Cir. 1962); Dairy Queen of Okla., Inc. v. Commissioner, 250 F.2d 503 (10th Cir. 1957).

93 Vern C. Moberg, 22 CCH Tax Ct. Mem. 1483 (1963); Dairy Queen of Okla., Inc., $18 \mathrm{CCH}$ Tax Ct. Mem. 322 (1959).

94 Dairy Queen of Okla., Inc., 18 CCH Tax Ct. Mem. 322 (1959).

95 Id. at 322.

$90 \mathrm{Id}$. at 324 .

97 Vern C. Moberg, 22 CCH Tax Ct. Mem. 1483, 1484 (1963).

98 Theodore E. Moberg, 35 T.C. 773, 776, 778 (1961). Gowdey had made fourteen sales in two years. Estate of Gowdey v. Commissioner, 307 F.2d 816, 817 (4th Cir. 1962).

99 Bauschard v. Commissioner, 279 F.2d 115, 118 (6th Cir. 1960); Gamble v. Commissioner, 242 F.2d 586, 590 (5th Cir. 1957); Rollingwood Corp. v. Commissioner, 190 F.2d 263, 266 (9th Cir. 1951).

100 Dunlap v. Oldham Lumber Co., 178 F.2d 781 (5th Cir. 1950); Snell v. Commissioner, 97 F.2d 891 (5th Cir. 1938). 
Although numerous sales of property do not automatically constitute a business, ${ }^{101}$ since the taxpayer has the right to liquidate his investments, the number of sales does act as an indication of a course or business of selling and of intent to hold for sale. ${ }^{102}$ In the Dairy Queen cases several of the franchisors, notably Dairy Queen of Oklahoma and the Mobergs, had made a substantial number of sales over a relatively brief period. Dairy Queen of Oklahoma had sold thirty-six subfranchises in two years; the Mobergs had made twenty-seven sales in four years; and Gowdey had made fourteen in two years. The Tax Court found that the sales were unsolicited in the first two cases, but it is well established that advertising and solicitation are not necessary to establish sales activity and sale in the ordinary course of business. ${ }^{103}$

Holding the property for only a short time before making the sales also strongly supports the inference that the property is held for sale in the ordinary course of business. ${ }^{104}$ The brief holding period suggests that the purchaser intended to sell when he obtained the property, and the courts have considered such a purpose to be a primary indication of holding for sale..$^{105}$ Also, the brevity of the holding period indicates that selling activity, not market value appreciation, was probably responsible for the gains from the sale. In Dairy Queen of Oklahoma, Gowdey, and Moberg, taxpayers made sales in the same year that they purchased their territorial franchises and continued to sell subfranchises steadily.

The territorial franchisors in these Dairy Queen cases did not simply sell their territorial franchises, but instead, in a pattern common throughout the service franchise systems, divided their territory into small marketing area franchises and sold them individually to operators. They thus converted their property, the territorial franchise, into something qualitatively different-numerous operating franchises-and, in effect, sold in a different market from the one in which they purchased. If the holder sells his property in the same market where he purchased it,

101 Barrios v. Commissioner, 265 F.2d 517 (5th Cir. 1959); Alabama Mineral Land Co. v. Commissioner, 250 F.2d 870 (5th Cir. 1957); White v. Commissioner, 172 F.2d 629 (5th Cir. 1949); Goldberg v. Commissioner, 16 T.C. 213 (1951).

102 Gamble v. Commissioner, 242 F.2d 586 (5th Cir. 1957); Rollingwood Corp. v. Commissioner, 190 F.2d 263, 266 (9th Cir. 1951); Dunlap v. Oldham Lumber Co., 178 F.2d 781 (5th Cir. 1950); Real Estate Corp. v. Commissioner, 35 T.C. 610, 615 (1961).

103 Mathews v. Commissioner, 315 F.2d 101 (6th Cir. 1963); Patrick v. Commissioner, 275 F.2d 437 (7th Cir. 1960); Lobello v. Dunlop, 210 F.2d 465 (5th Cir. 1954); DiLisio v. Vidal, 135 F. Supp. 114 (D.N.M. 1955), aff'd, 233 F.2d 909 (10th Cir. 1956); Real Estate Corp. v. Commissioner, 35 T.C.' 610 (1961).

104 See Tidwell v. Commissioner, 298 F.2d 864 (4th Cir. 1962); Burgher v. Campbell, 244 F.2d 863 (5th Gir. 1957); Raymond Bauschard, 31 T.C. 910 (1959), affd, 279 F.2d 115 (6th Cir. 1960).

105 See note 97 supra. 
the presumption, absent some clear service he is performing for compensation, is that his profit derives from fluctuation of the market price and represents market value appreciation. ${ }^{106}$ Conversely, when the franchisor sells in a different market, he loses this presumption. ${ }^{107}$ If the seller is subdividing and selling in a different market, a comparison of the return on sale of the whole territorial franchise with the returns from the sale of the operating franchises would give some indication of sales activity gains. The value of the whole represents the simple market value appreciation, and anything substantially in excess of that earned by the operating franchise sales represents return for development and sales activity. ${ }^{108}$ The situation is similar to that of the land subdivision cases, where some of the courts have held that subdivision may constitute sufficient sales activity to put the seller in the business of selling. ${ }^{109}$

100 Seltzer, The Nature and Tax Treatment of Capital Gains and Losses 3 (1951). 107 Ibid.

108 There are sereral problems with such a comparison test. Since the subfranchises are sold over a period of years, it is diffcult to decide in what year the value of the whole is to be measured for comparison. Comparisons with total values for every year are awkward, so the year of the latest sale in the series before the court is probably the best point for making the estimate of total value. This is certainly fair to the seller, and so long as the period under consideration is short (two or three years in the Dairy Queen cases), it should not result in too great distortion.

Also, it is difficult to estimate, for purposes of comparison, just what percentage of the total value of the franchise has been sold. The territorial franchisors have had a similar valuation problem in allocating the purchase price for their territory as basis for operating franchises. Their solution has been to allocate on the basis of population, and a similar approach could be used here. The subfranchise price could be compared with the share of the total value allocable to that subfranchise area on the basis of its population.

Any such comparison is rough at best, and is only indicative of a business of selling if the subfranchise sales produce much more income than the sale of the entire territory would produce. If there is no such disparity, it does not necessarily indicate a simple investment, but may instead indicate that the territorial franchise is valued by purchasers in terms of the expected revenues from the sale of subfranchises, in which case, the business is one of professional subdivision and is essentially a merchandising venture, deserving no favorable tax treatment.

109 Nadalin v. United States, 364 F.2d 431, 439 (Ct. Cl. 1966); Achong v. Commissioner, 246 F.2d 445 (9th Cir. 1957) (property held for 23 years, then subdivided and sold through agents held to produce ordinary income); Richards v. Commissioner, 81 F.2d 369 (9th Cir. 1936) (held the subdivision done by trustee was to obtain a larger profit on sale and profit was ordinary income); Robert G. Elbert, 16 CCH Tax Ct. Mem. 449 (1957).

Although these subdivision cases often involve considerable development activity such as construction of streets and sewers, an inquiry into the activities of the territorial franchisor might reveal analogous development and sales activity for the franchise territorythe establishment of the trade name through advertising, the location of operating sites, and the establishment of purchasing and communication systems for prospective operators. This activity, if present, reinforces the evidence of subdivision and strengthens the inference that the territorial franchisor is a seller rather than an investor and that his return is at least in part a return for sales activity. 
In addition, the courts might find it useful to examine the general pattern of activity of territorial franchisors in service franchise systems. If the function of the territorial franchisor is generally considered to be the sale and supervision of operating franchises, and if territorial franchises are sold with the understanding that the franchisor is expected to reap his profits at least in part from the sale of subfranchises, then it is difficult to see how the territorial franchisor can enter the business with any intent other than to subdivide and sell. ${ }^{110}$ Intent to sell is clear from the context, and the subfranchises would thus appear to be "property held primarily for sale in the ordinary course of business," producing ordinary income when sold. ${ }^{111}$

Dairy Queen of Oklahoma, the Mobergs, and Gowdey made frequent sales, held for very short periods, subdivided, and made large profits selling the resulting subfranchises. A more thorough exploration of the surrounding facts might have revealed that selling franchises was in fact the business of these three operations and that gains from such sales should have been taxed at ordinary rates. ${ }^{112}$

\section{CoNCLUSTON}

In the transfer of service franchise subfranchises, the territorial franchisor attaches conditions in the contract, bases his payment on a percentage of sales, subdivides his master franchise, and sells the resulting subfranchises frequently after holding the property only briefly. In attempting to determine whether the gains from these transfers qualify for capital gains treatment, the courts in the Dairy Queen cases have utilized the sale and exchange requirement to differentiate a capital gain from an ordinary income transaction. However, the sale and exchange framework is not a helpful approach to the franchise problem. The conditions which the courts have sometimes held to indicate an intent to license rather than to sell can be justified as reasonably necessary for the protection of the franchisor. Such provisions do not violate

110 The amount of return from selling when compared with other activity of the taxpayer has been considered a relevant test for sale in the course of business. Matthews v. Commissioner, 315 F.2d 101 (6th Cir. 1963); United States v. Beard, 260 F.2d 81 (9th Cir.), cert. denied, 358 U.S. 874 (1958); Murray v. Commissioner, 238 F.2d 137 (10th Cir. 1956).

111 The single venture has been considered a business where the intent of the purchasers of the asset was immediate resale. See Hollis v. United States, 121 F. Supp. 191 (N.D. Ohio 1954) (art syndicate to purchase Japanese art with intent to sell to museums); Raymond Bauschard, 31 T.C. 910 (1959) (purchase of a single property which was subdivided and resold immediately held to produce ordinary income).

112 The same result would seem to follow for sales of subfranchises from the national level, see note 4 supra, if the master franchise were held for a very short period and the subfranchise sales were frequent. 
the sale and exchange requirement, and all gains on the sale of the subfranchise, in whatever form, should be given capital gains treatment, if sale were the only problem.

However, sale is not the only problem raised by franchise transfers, and a better approach would be a more thorough examination of the territorial franchisor's mode of operation in selling subfranchises. ${ }^{113}$ His subdivision of the franchise coupled with the frequency of sales and the brevity of the holding period in many of the cases indicates that quick sale and not investment is the primary intent of the franchisor. The territorial franchisor who engages in these activities is holding subfranchises primarily for sale in the ordinary course of business, and any gains on such sales should be taxed at ordinary rates.

113 For another possible approach to the sale of contract rights based an extension of the doctrine of Corn Products Refining Co. v. Commissioner, 350 U.S. 46 (1955), to cover most or all business property which is not real or depreciable, see Chirelstein, Capital Gains in the Sale of a Business Opportunity: The Income Tax Treatment of Contract Termination Payments, 49 MINN. L. REv. 1 (1964). 